\title{
Analysis of the building system of four mills and their suitability for heat treatment pest disinfestation
}

\author{
Loredana Strano, Giovanna Tomaselli \\ Department of Agri-food and Environmental Systems Management, Section: Building and Land \\ Engineering, University of Catania, Catania, Italy
}

\section{Abstract}

The last century researchers at Kansas State University demonstrated the validity of the heat treatment as a method of pest control in more than 20 mills. However factors such as the high capital investment required to heat large buildings, inadequate control of high temperatures and the risk of damage to parts of the plants or the construction materials have prevented the large-scale adoption of this technique as a viable alternative to fumigants. Today the combination of the industrialization of the food industry, the technological and structural modernization of plants and developments in heat disinfection technologies have resulted in interesting results being obtained for the use of this system in primary and secondary production processing plants, both experimentally and in practice. However, the scientific literature highlights some of the factors that limit the efficiency of the treatment. This is related to aspects of the buildings and the plants and the environment of the buildings. The structure of the buildings appear to have an enormous impact on energy consumption, because this depends on the amount of heating time and the methods that have to be used when establishing a heat treatment regime. These factors are important if the fumigation temperatures are to be reached in the shortest possible time and can affect the choice of the technique used with current fumigants, especially when this is combined with the amount and cost of the energy consumed. The aim of this work is to analyse four Sicilians mills that intend to use the heat system for fumigation and pest control in order to identify those aspects of the buildings, plant and their environment which are "critical elements" and may discourage the use of this technology. Particular attention was paid to the type of construction materials and their thermal conductivity (roof, floors and walls), the number and volume of the buildings and the distance between them, the entrances and the links between different parts of the plant and the type of equipment used and its spatial organisation inside the buildings.

Correspondence: Giovanna Tomaselli, Department of Agri-food and Environmental Systems Management, Section: Building and Land Engineering, University of Catania, Via S. Sofia 100, 95123, Catania, Italy. E-mail: gitomas@unict.it

Key words: buildings, heat, pest control, plant

(C) Copyright L. Strano and G. Tomaselli., 2013

Licensee PAGEPress, Italy

Journal of Agricultural Engineering 2013; XLIV(s2):e149

doi:10.4081/jae.2013.s2.e149

This article is distributed under the terms of the Creative Commons Attribution Noncommercial License (by-nc 3.0) which permits any noncommercial use, distribution, and reproduction in any medium, provided the original author(s) and source are credited.

\section{Introduction}

The first example of the use of heat treatment pest disinfestation in the milling sector was in a document published by Duhamel du Monceau in France in 1762 (Beckett et al., 2007).

In 1912 Professor G. A. Dean, an entomologist at Kansas State Agricultural College, demonstrated the efficicacy of heat treatment for controlling insect infestation in a study carried out at 20 mills in Ohio, Illinois, Indiana, Iowa, Nebraska and Southern Canada, and proposed that this method was a valid alternative to the use of fumigants (Dean, 1911, 1913; Field et al., 1997; Dosland, 1996).

More recently pilot studies using heat treatment with biotesting have been carried out at mills in Canada and Europe by Kansas State University. These studies have demonstrated that the temperature at which the insects die was on average between $40{ }^{\circ} \mathrm{C}$ and $55^{\circ} \mathrm{C}$. The available data shows that most species of insects do not survive for more than: 24 hours at $40{ }^{\circ} \mathrm{C}, 12$ hours at $45{ }^{\circ} \mathrm{C}, 5$ minutes at $50{ }^{\circ} \mathrm{C}$, and only 1 minute at $55^{\circ} \mathrm{C}$ (Suss, 2007; Brijwani et al., 2010, 2012).

In addition various experiments in agro-industrial plants in Italy and abroad have demonstrated that to reach $100 \%$ insect mortality one needs a treatment period of 36 to 48 hours at temperatures between $55^{\circ} \mathrm{C}$ and $60{ }^{\circ} \mathrm{C}$.

An experiment carried out in a $11.500 \mathrm{~m}^{3}$ brick-built mill in 2007 was able to evaluate the heat loss during treatment. $44 \%$ of the heat was absorbed by the floor and walls and $10 \%$ by the plant, while $46 \%$ was related to the heat loss of the building (Guerra, 2009).

The most recent reports in the literature have highlighted certain aspects of the buildings, plant and environment which may limit the efficacy of heat treatment.

It is known that the main critical points in mills are the "cold points", i.e. the spaces in which the temperatures do not reach the required levels. Certain studies have shown how, during treatment, various types of insect move to the areas where the temperatures do not reach lethal levels (Massara 2007; Suss, 2008; Guerra et al., 2012). These critical points are linked to the characteristics of the materials used for the buildings and plant and the organisation of the buildings themselves. These factors influence the choices of how the treatment is applied (type of thermo-ventilator fans, season, time period and temperature of treatment), and thus the cost of the energy consumed, and the management of the operation (Braghieri et al., 2007; Massara, 2007; Suss, 2008; Guerra, 2009).

At present it seems that innovations to the plant designed to ensure their efficiency when subjected to high temperatures are more advanced than the general level of innovation of the typical layout of the mills themselves, and also more advanced than the types of construction and the materials used to ensure a suitable environment for heat treatment.

Today, because of the good results of heat treatment pest disinfestation, more and more businesses are interested in and intend to use this system. However many of the buildings do not have the correct 
characteristics and are not constructed of the right materials to guarantee good results.

Given that these problems exist, this paper studies four mills, in order to identify the critical points. The information obtained may be useful in helping to make existing structures suitable for heat treatment and also helpful when planning new mills.

\section{Materials and methods}

The paper studies four Sicilian mills whose owners intend to use heat treatment pest disinfestation. Thermo-ventilator fans will be used to heat the four mills, with each fan using about $20 \mathrm{~kW} / \mathrm{h}$ of electricity. On average three ventilator fans will be used for a volume of $1000 \mathrm{~m}^{3}$.

Mills 1 and 2 are in the Province of Syracusa and mill daily, respectively, 220 tons of durum wheat and 100 tons of common wheat. Mill 3 is in the Province of Enna and mills 0.3 tons of durum wheat per day, with the flour being to used in the bakery attached to the mill. Mill 4 is in the Province of Palermo and mills 220 tons of durum wheat per day for use in the bakery attached to the mill.

The mills are built according to the standard layout used by the major construction companies.

All the mills have a central building, with the height depending on the production capacity, divided into different floors, as can be seen in Figure 1. The standard layout is adequate for the production flow and, irrespective of the particular capacity, the silos are connected laterally to the central building. The plan in Figure 1 shows a mill with a capacity of 220 tons per day.

Analysis of the problems and direct observation of the mills has allowed us to acquire detailed information of the characteristics of the buildings and the relationships between them and the production processes.
The precise investigation of the critical points was only carried out in the places where heat treatment would be used. In order to do this aspect of the buildings and plant were used as indicators.

The aspects of the buildings, using meta-planning methods (Failla et al., 2006; Strano et al., 2012) as a point of reference, were extrapolated from the building systems used (UNI EN 10723:1998; UNI EN 10838:1999):

- the environment and type of building, in order to identify the critical points in heat distribution in the different areas and between the floors. In order to do this the volumes and the way that the different floors were connected were taken into consideration;

- the technological system, so as to identify the critical points in heat loss and the response of the materials used. In order to do this, the characteristics of the construction materials, the plant and the surface of the walls floors and roofs were taken into consideration.

For the aspects of the plant, the processing plant were analysed in order to identify possible equipment or parts of the plant which were "sensitive to heat treatment". The companies which construct many of the components supplied information on their heat resistance characteristics. In this way these values were acquired and systematised. For those components or plant where the information was not provided by the suppliers, laboratory tests were developed to check their resistance to high temperatures. To be more precise, samples of the sieves, the square sifters and the purifiers from the four mills, made up of wooden and aluminium sieve frames, assembled with cyanoacrylate adhesive or vinyl glue, were placed in a closed environment for 48 hours in a temperature of $63^{\circ} \mathrm{C}$.

\section{Results and discussion}

The results below take into consideration developments in the liter-

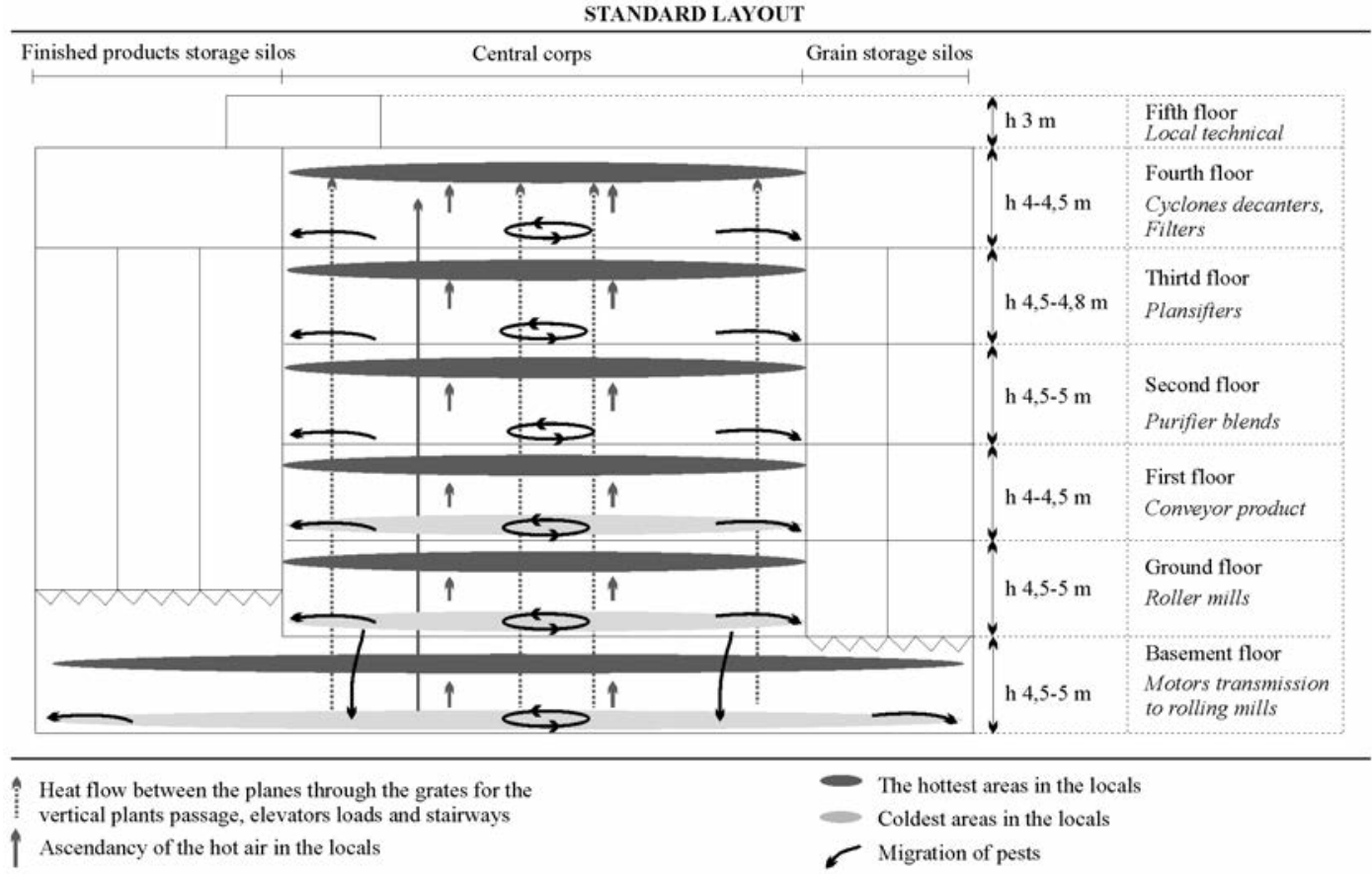

Figure 1. Heat distribution in the plans and possible migration of pests. 
ature in recent years. Thus it is implicit that when highlighting the critical points in the mills we studied one must take into account the views expressed in the pricipal scientific literature for this sector (Beckett et al., 2007; Massara, 2007; Süss, 2008; Guerra; 2009).

\section{Aspects of the buildings and critical points}

The characteristics of the building system used in the four mills are shown in Tables 1 and 2. The processing environment, in different places depending on the type of layout, although always compartmentalised, present points of continuity in correspondence with the many openings in the ceilings, which are necessary for connecting the different plant. As a result it is difficult to check the thermo-hygrometric parameters of each environment: to intervene in one would mean intervening in the whole volume of the building (Table 1).

Table 2 shows the construction system used for the four mills. They all of the traditional type and have insulating material only on the external walls.

\section{The critical points identified in the analysed building systems}

If one intends to use heat treatment in the mills, the critical points essentially refer to heat movement upwards from the lower floors to the upper ones. This causes temperature differences between the different floors and between the surfaces of the roofs, ceilings, walls and floors, as can be seen in Figure 1. Other critical points are linked to the characteristics of the construction material used.

Certain critical points were found in all four mills. To be precise, the areas used for the milling machines may be critical points for heat transfer due to the following aspects of the buildings:

- the longitudinal gratings of the vertical pneumatic conveyors of the products;

openings in the horizontal partitions for housing the freight elevators;

- shutters.

Other specific points of heat loss in the different mills are:

Mill 1 (Figure 2A and 2B)

- transversal gratings between the walls and floors used for housing the Archimedian screws that transfer the grain. These are found between all the floors, from the basement to the fifth floor;

open areas designed to house the iron silos for storing the flour awaiting packaging. These are found between the second and fourth floors of the mill;

Mill 2 (Figure 3)

internal staircase without doors;

openings in the ceiling between the basement and the ground floor in correspondence to the location of the flour storage silos;

Mill 3 (Figure 4)

internal staircase without doors;

Mills 3 and 4 (Figure 4)

trapdoors for the ramps for the sacks; central openings between the floors for the pneumatic machinery and for the conveyor belts.

The effects of the hot air rising and its stratification are particularly evident vertically, as the vertical areas are more difficult to heat uniformly than the horizontal ones.

In the mills under investigation the vertical spaces are found near the internal grain or flour storage silos or near the storage spaces for the unpackaged final products.

Other elements which may effect the uniform distribution of temperatures are the external walls, which are more exposed to heat exchange with the surrounding area.

At present the methods used for heat treatment use ventilator fans to circulate the air, This ensures that the ambient temperature is uni- form and that the lower areas are also heated.

Analysis of studies on heat treatment in mills indicates that the zones where the pests migrate to often coincide with the following areas, which are those where it is most difficult to apply the heat treatment:

- the junctions between floors and walls, walls and walls, roofs and walls, as well as the spaces between the plant and the floors; crevices and cracks in the walls and floors;

the spaces between the walls and the plant or the frames on which the machinery is mounted. (Dowdy, 1999; Dowdy and Field 2002;

Mahroof et al., 2003; Hulasare et al., 2010; Guerra et al., 2012)

Bearing in mind the observations of the migration of the pests, a report has been developed for the mills under consideration which indicates the colder points of the various work spaces (Figures 1,2,3 and 4).

The critical points inherent in the characteristics of the construction material are basically due to the way the material used for the buildings and plant aids heat loss.

From our observations and from information obtained during the experiment one can arrive at certain conclusions.

The mills generally have brick walls and concrete, granite or marble floors. These heat more slowly during the heating process. The plant and machinery are made of aluminium or iron and do not present any particular critical points during the heating process, although the seals may be damaged. The floors in mill 3 are connected by ramps covered in plastic, and this may be damaged by the high temperatures during heat treatment.

The heat retention of the buildings depends on the characteristics of the bricks used, which have different levels of conductivity, and the presence or absence of insulation (Table 2). The mills have insulated walls and roofs, with the exception of mill 3 . Thus this is the one where there is likely to be more heat loss during treatment.

Other critical points may be the internal horizontal partitions which are not insulated, and so contribute to the upwards heat transfer in the buildings. The areas in the basements are always colder than the areas in the upper floors.

Mills 1 and 2 have external single glazed windows in aluminium frames, These prevent air escaping but are not efficacious for heat retention.

Mills 3 and 4 have windows with old iron frames which are often not airtight. During heat treatment even the smallest cracks may be significant critical points for heat loss.

Table 1. Volumes of local mills.

Production space $\quad$ Volumes $\mathrm{m}^{3} \quad \begin{gathered}\text { Volumes bring } \\ \text { thermal regime } \\ \text { Total } \mathrm{m}^{3}\end{gathered}$

Mill 1

$\begin{array}{lcc}\text { Grain storage } & 6576 & 23131 \\ \text { Milling } & 11589 & \\ \text { Durum wheat and waste storage } & 4966 & \\ \text { Mill 2 } & & 7295 \\ \text { Milling and storage } & 7295 & 1175 \\ \text { Finished products storage } & 5040 & \end{array}$

Mill 3

Milling and storage

5000

Mill 4

Milling and storage

Finished products storage

Waste storage 

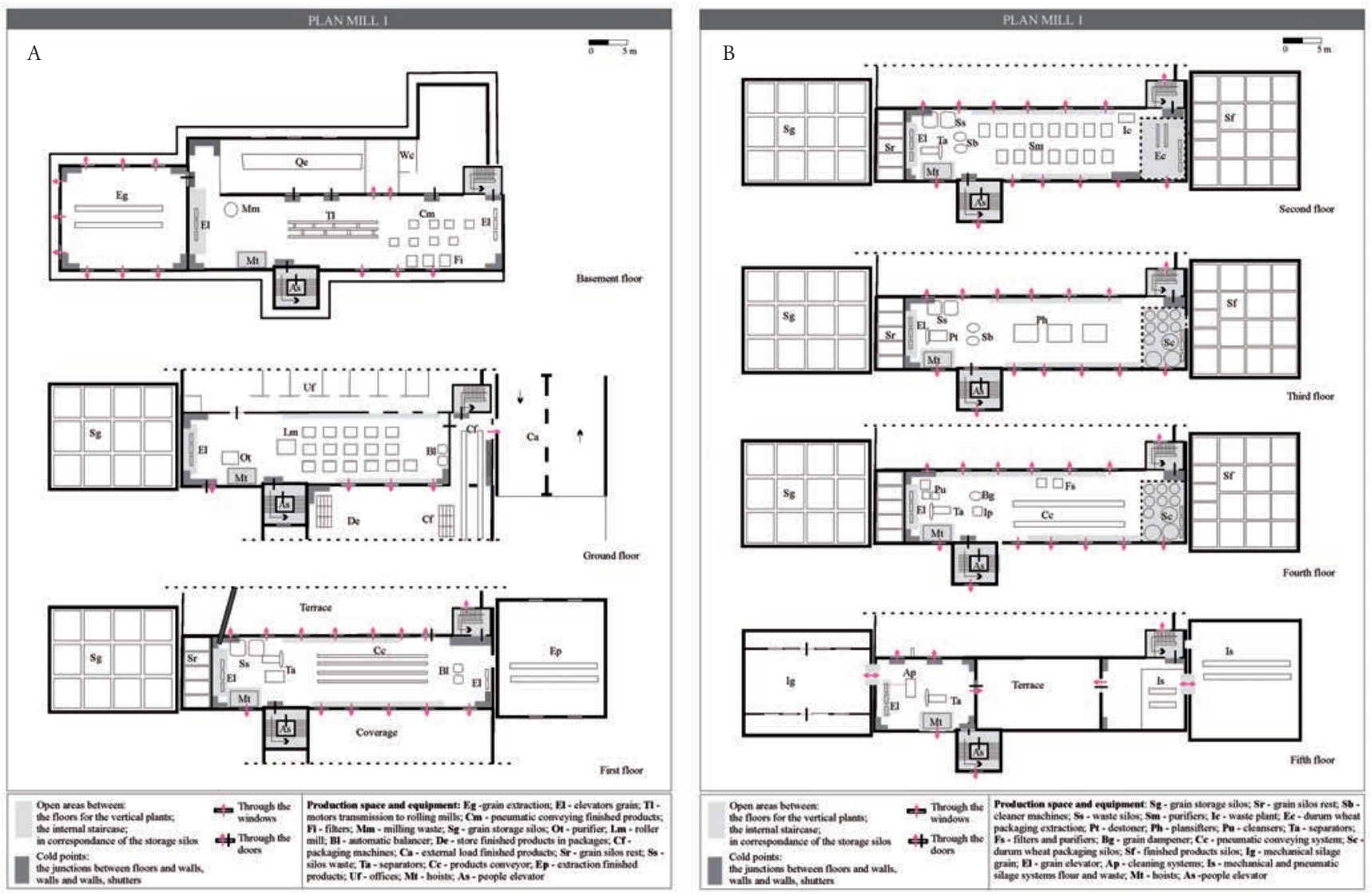

Figure 2. Critical points for transfer of heat.

Table 2. Construction characteristics of the mills and their critical points.

\begin{tabular}{|c|c|c|c|c|c|c|c|c|c|c|}
\hline $\begin{array}{l}\text { Production } \\
\text { areas }\end{array}$ & \begin{tabular}{|l}
$\begin{array}{l}\text { Support } \\
\text { structures }\end{array}$ \\
\end{tabular} & Lofts & Floors & External walls & $\begin{array}{l}\begin{array}{l}\text { Internal } \\
\text { walls }\end{array} \\
\end{array}$ & Roofs & Ceilings & Doors & & Windows \\
\hline Mill 1 & & & & & & & & Internal & External & External \\
\hline Grain store & \multirow{3}{*}{$\begin{array}{l}\text { Base with } \\
\text { reinforced } \\
\text { concrete grade } \\
\text { beams and } \\
\text { reinforced } \\
\text { concrete } \\
\text { foundations }\end{array}$} & \multirow{3}{*}{$\begin{array}{l}\text { A mixture of } \\
\text { reinforced } \\
\text { concrete } \\
\text { with } \\
\text { prefabricated } \\
\text { reinforced } \\
\text { concrete } \\
\text { beams and } \\
\text { brickwork }\end{array}$} & \multirow{3}{*}{$\begin{array}{l}\text { Industrial } \\
\text { quartz } \\
\text { flooring } \\
\end{array}$} & \multirow[t]{3}{*}{$\begin{array}{l}\text { Double brick } \\
\text { walls with } \\
\text { insulation in } \\
\text { between them }\end{array}$} & $\begin{array}{l}\text { Raw } \\
\text { concrete/pl } \\
\text { aster }\end{array}$ & \multirow[t]{3}{*}{$\begin{array}{l}\text { Reinforced } \\
\text { concrete } \\
\text { with } \\
\text { insulation }\end{array}$} & $\begin{array}{l}\text { Raw } \\
\text { concrete/pl } \\
\text { aster }\end{array}$ & Idra REI 120 & \multirow[t]{3}{*}{$\begin{array}{l}\text { Aluminiu } \\
\mathrm{m} \text { and } \\
\text { glass }\end{array}$} & \multirow[t]{3}{*}{$\begin{array}{l}\text { Pre-painted } \\
\text { aluminium } \\
\text { and single } \\
\text { glazing }\end{array}$} \\
\hline Milling area & & & & & $\begin{array}{l}\text { Raw } \\
\text { concrete }\end{array}$ & & $\begin{array}{l}\text { Raw } \\
\text { concrete }\end{array}$ & $\begin{array}{l}\text { Fireproof } \\
\text { doors }\end{array}$ & & \\
\hline $\begin{array}{l}\text { Flour and waste } \\
\text { store }\end{array}$ & & & & & $\begin{array}{l}\text { Raw } \\
\text { concrete/pl } \\
\text { aster }\end{array}$ & & $\begin{array}{l}\text { Raw } \\
\text { concrete/pl } \\
\text { aster }\end{array}$ & & & \\
\hline \multicolumn{11}{|l|}{ Mill 2} \\
\hline $\begin{array}{l}\text { Milling and } \\
\text { storage areas }\end{array}$ & $\begin{array}{l}\text { Reinforced } \\
\text { concrete }\end{array}$ & \multirow[t]{2}{*}{$\begin{array}{l}\text { Reinforced } \\
\text { concrete }\end{array}$} & \multirow[t]{2}{*}{$\begin{array}{l}\text { Industrial } \\
\text { cement }\end{array}$} & \multirow{2}{*}{$\begin{array}{l}\text { Hollow brick } \\
\text { with insulating } \\
\text { material } \\
\text { between them } \\
\text { Prefabricated in } \\
\text { cement }\end{array}$} & \multirow[t]{2}{*}{$\begin{array}{l}\text { Raw } \\
\text { concrete/pl } \\
\text { astero }\end{array}$} & \multirow[t]{2}{*}{$\begin{array}{l}\text { Reinforced } \\
\text { concrete } \\
\text { with } \\
\text { insulation }\end{array}$} & $\begin{array}{l}\text { Raw } \\
\text { concrete }\end{array}$ & Absent & $\begin{array}{l}\text { Aluminiu } \\
m \text { and } \\
\text { glass }\end{array}$ & $\begin{array}{l}\text { Aluminium } \\
\text { and single } \\
\text { glazing }\end{array}$ \\
\hline $\begin{array}{l}\text { Final product } \\
\text { store }\end{array}$ & $\begin{array}{l}\text { Prefabricated } \\
\text { in cement }\end{array}$ & & & & & & $\begin{array}{l}\text { Prefabricat } \\
\text { ed in metal }\end{array}$ & - & $\begin{array}{l}\text { Sectional } \\
\text { doors }\end{array}$ & $\begin{array}{l}\text { Metal and } \\
\text { single } \\
\text { glazing }\end{array}$ \\
\hline \multicolumn{11}{|l|}{ Mill 3} \\
\hline $\begin{array}{l}\text { Milling and } \\
\text { storage areas }\end{array}$ & $\begin{array}{l}\text { Reinforced } \\
\text { concrete }\end{array}$ & $\begin{array}{l}\text { Reinforced } \\
\text { concrete }\end{array}$ & $\begin{array}{l}\text { Marble } \\
\text { granite }\end{array}$ & $\begin{array}{l}\text { Reinforced } \\
\text { concrete blocks } \\
\text { without } \\
\text { insulation } \\
\end{array}$ & $\begin{array}{l}\text { Raw } \\
\text { concrete/pl } \\
\text { aster }\end{array}$ & $\begin{array}{l}\text { Reinforced } \\
\text { concrete } \\
\text { without } \\
\text { insulation } \\
\end{array}$ & $\begin{array}{l}\text { Raw } \\
\text { concrete }\end{array}$ & Absent & $\begin{array}{l}\text { Iron and } \\
\text { plexiglas }\end{array}$ & $\begin{array}{l}\text { Iron and } \\
\text { plexiglas }\end{array}$ \\
\hline \multicolumn{11}{|l|}{ Mill 4} \\
\hline $\begin{array}{l}\text { Milling and } \\
\text { storage areas } \\
\text { Final products } \\
\text { store } \\
\text { Waste products } \\
\text { store } \\
\end{array}$ & $\begin{array}{l}\text { Reinforced } \\
\text { concrete with } \\
\text { beams and } \\
\text { columns with } \\
\text { closed mesh } \\
\text { frames } \\
\end{array}$ & $\begin{array}{l}\text { Masonary } \\
\text { cement } \\
\text { screed and } \\
\text { cement } \\
\text { bricks }\end{array}$ & $\begin{array}{l}\text { Marble } \\
\text { granite }\end{array}$ & $\begin{array}{l}\text { Calcarenite } \\
\text { blocks in } \\
\text { pomice blocks }\end{array}$ & Plaster & $\begin{array}{l}\text { Reinforced } \\
\text { concrete } \\
\text { without } \\
\text { insulation }\end{array}$ & Plaster & $\begin{array}{l}\text { Iron and } \\
\text { glass }\end{array}$ & $\begin{array}{l}\text { Aluminiu } \\
\mathrm{m} \text { and } \\
\text { glass }\end{array}$ & $\begin{array}{l}\text { Iron and } \\
\text { single } \\
\text { glazing }\end{array}$ \\
\hline
\end{tabular}




\section{Aspects of the plant and critical points}

In mills transforming grain into flour involves the following processing stages: collection, pre-cleaning, storage, cleaning, drying, milling and processing, storage of the flour and packaging of the final product.

These processes involve the use of different machinery and plant (Table 3). These may be damaged by heat treatment.

\section{Critical points identified in the plant}

Analysis of the plant found that the storage silos in concrete or steel, zinc or iron sheet metal are not damaged by the temperatures used during heat treatment.

The cleaning, milling and sieving machinery in mills 1,2 and 4 were made of stainless steel by Bühler S.p.A and there are no critical points at high temperature. There are also no problems for the aluminium or treated-wood sieves, the rubber components (seals, couplings, etc.), the PVC trapezoidal transmission belts, the flat leather transmission belts, the plexiglas bells, the fibreglass or wood rods or the special synthetic sleeving material.

The plant used in mill 3 for cleaning and milling are old machines from the 1980s made by Golfetto Italia. They are made of steel and/or wood with mahogany or American tulipwood equipment. The suppliers maintain that the materials used should be resistant to heat treatment.
However the information obtained during the research suggests that some equipment may be sensitive to heat treatment, especially the following:

- $\quad$ sieve frames used during sifting;

- parts and components of the packaging machinery;

- $\quad$ equipment and parts of machinery which have become worn out through use.

During sifting the critical points were identified as the sieve frames with nylon nets. The strength of the attachment depended on the type of glue used.

Tests on frames in wood and aluminium assembled using cyanoacrylate adhesive, found that the structures resisted high temperatures and the frames were not deformed.

The components of the packing and flour plant and machinery were found to be sensitive to the heat treatment (Table 3 ).

\section{Conclusions}

This study highlights the critical points for heat treatment in four representative mills. Most critical points were due to lack of insulation.

\section{PLAN MILL 2}

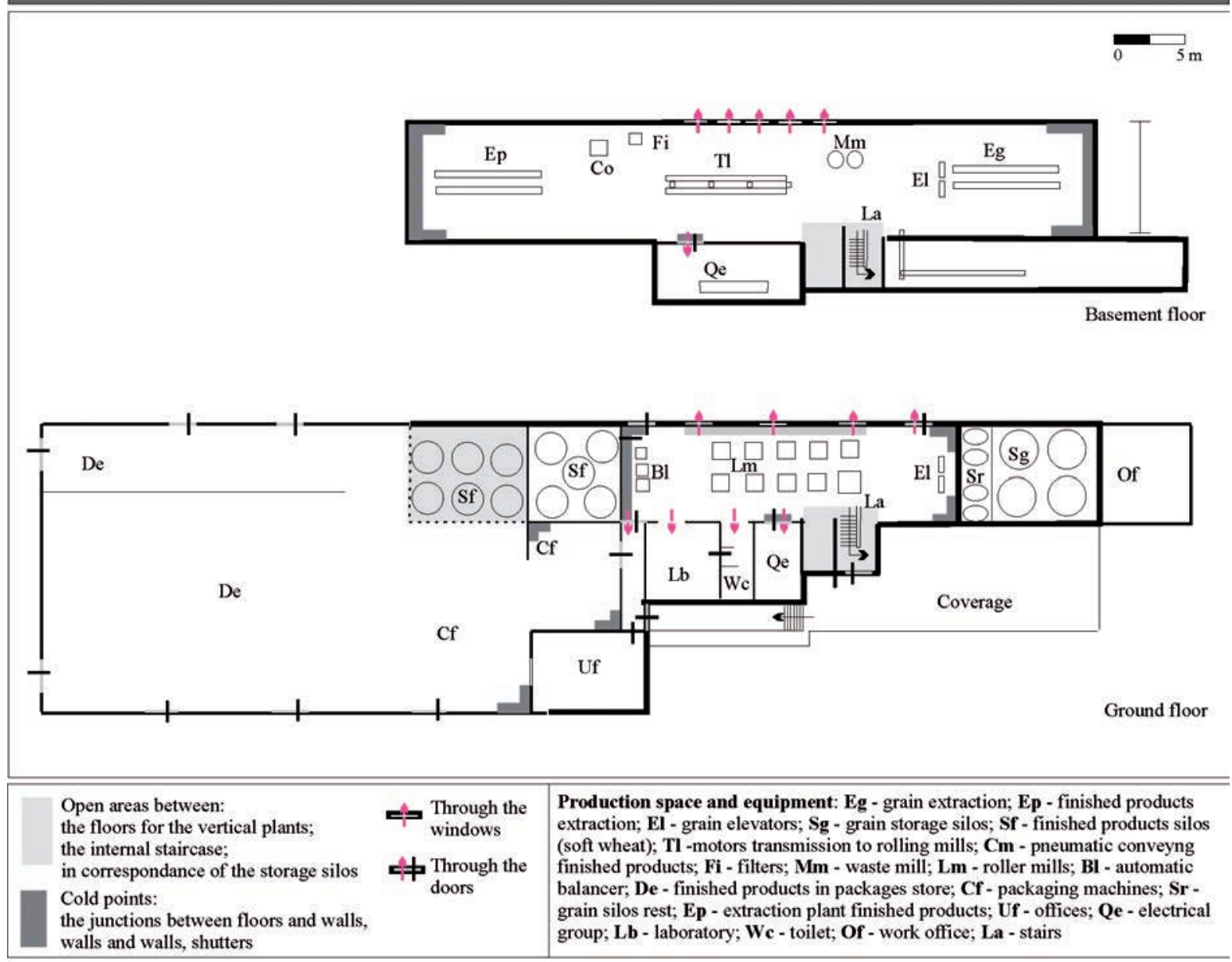

Figure 3. Critical points for transfer of heat. 
This was only used for external walls in the various buildings.

Other aspects of planning, which are apparently of minor importance, such as for example isolating the different environments vertically, must be treated with particular care in buildings where heat treat- ment is intended to be used as a standard procedure for combating pest infestation.

Traditional mills may be built of different materials, usually metal structures, prefabricated panels or steel. These have the advantage of
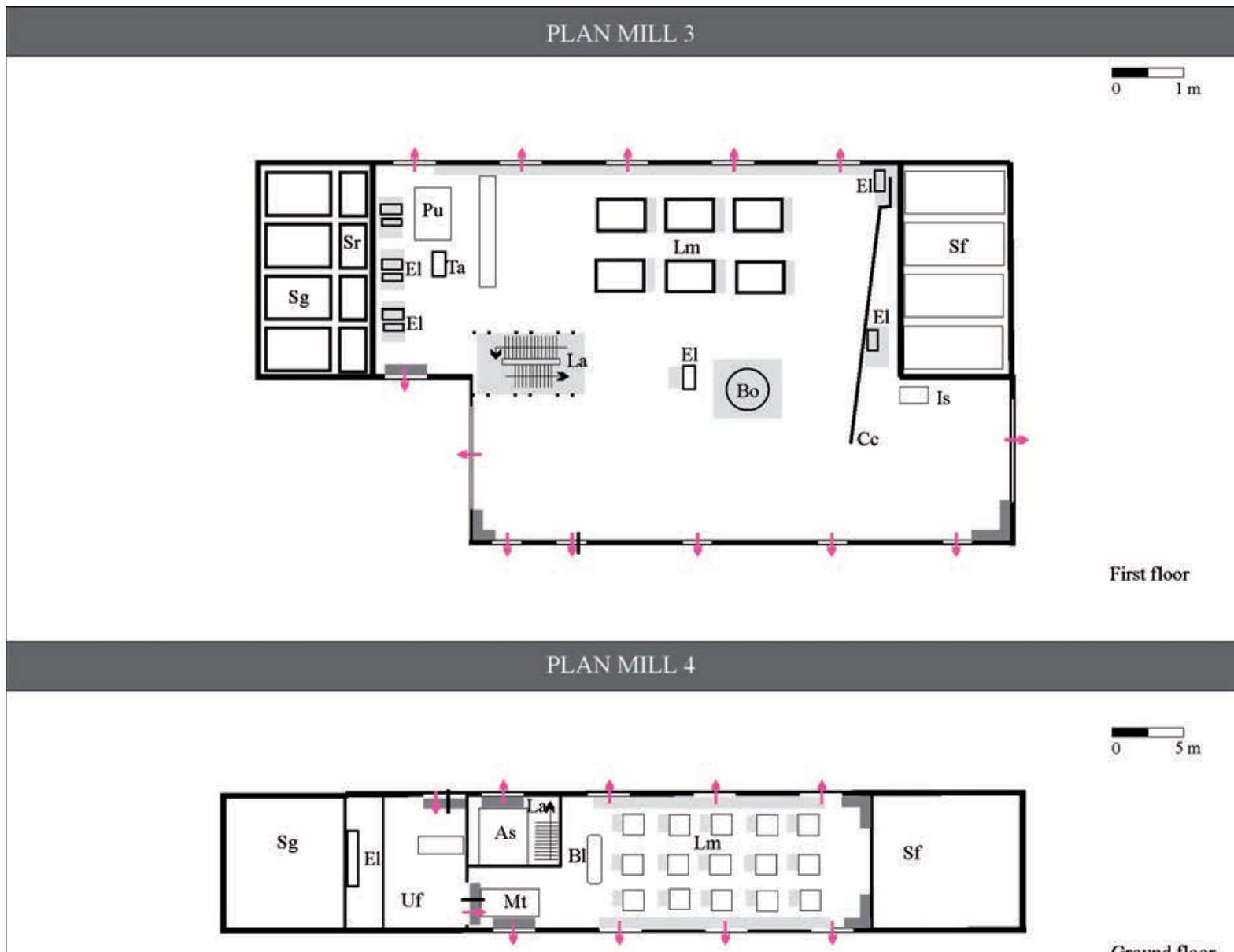

Ground floor

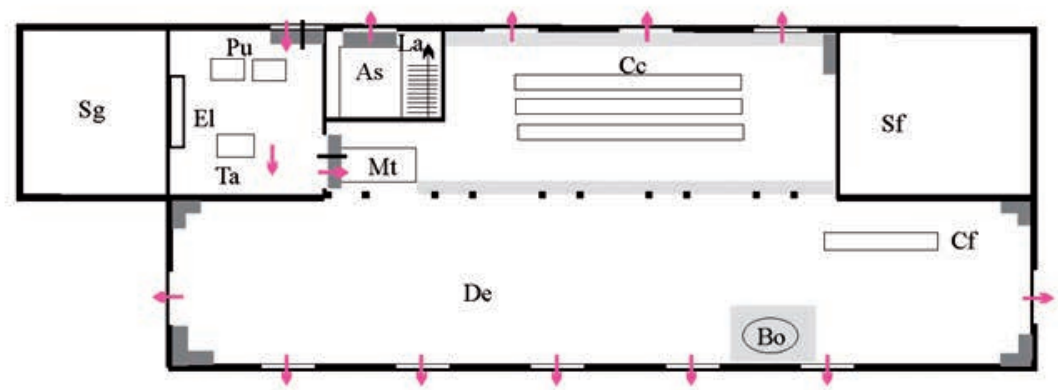

First floor

Open areas between:
the floors for the vertical plants;
the internal staircase;
in correspondance of the storage silos
Cold points:
the junctions between floors and walls,
walls and walls, shutters

Production space and equipment: $\mathbf{S r}$ - grain silos rest; $\mathrm{EI}$ - grain elevators; $\mathbf{S g}$ grain storage silos; Sf - finished products silos (durum wheat); Bo-hatch slips packaging; Pu - cleansers; Lm - roller mills; Bl - automatic balancer, De - finished products in packages store; $\mathbf{C f}$ - packaging machines; Ta - separators; Cc conveying sistem; Uf - offices; Mt - hoists; As -people elevator, La - stairs

Figure 3. Critical points for transfer of heat. 
Table 3. Identification of plant components susceptible to heat treatment.

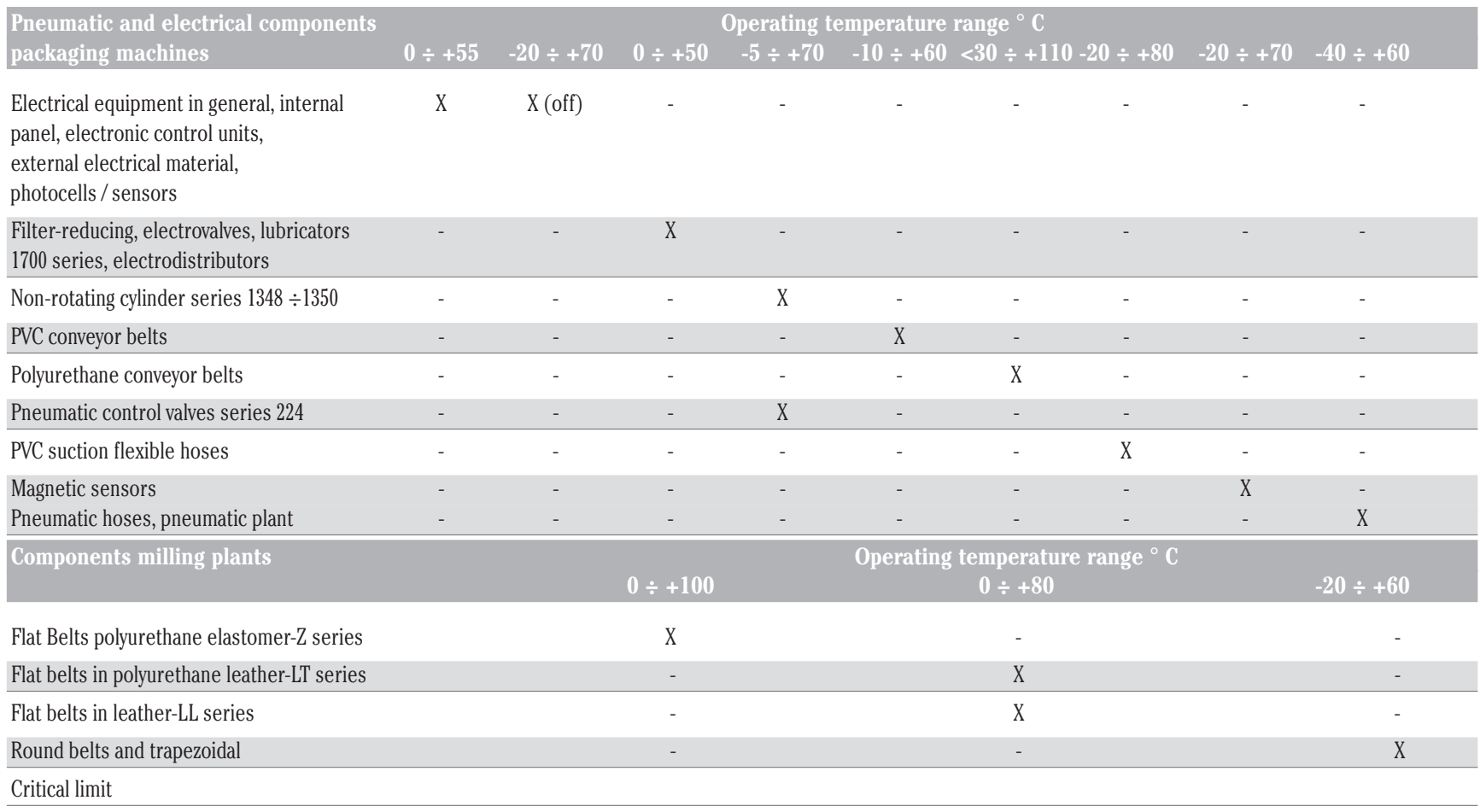

allowing the desired temperatures to be reached in a short time.

Very few critical points were found among the plant. The suppliers are ensuring that the components of the plant are suitable for the requirements of heat treatment.

The results of the analysis are of fundamental importance in establishing guide lines which can be used for existing buildings and when planning new mills, because heat treatment pest disinfestation is becoming ever more widely used $n$ this sector.

\section{References}

Beckett S. J., Subramanyam B., Fields P. G. 2007. Disinfestation of Stored products and associated structures using heat. In: J. Tang, et al. (eds) Heat treatments for postharvest pest control. CABI, Wallingford, Oxfordshire, UK, pp 182-94.

Braghieri G., Nervi F \& Zini N. 2007. Aspetti applicativi di nebbia secca e/o disinfestazioni con aria calda. pp 24-31 in Proc. Conf. L'eliminazione del bromuro di metile per la disinfestazione di industrie alimentari e strutture. Risultati di due anni di esperienze pratiche, 15 February, Bologna, Italy.

Brijwani M., Subramanyam B., Flinn P. W. 2012. Susceptibility of Tribolium castaneum Life Stages Exposed to Elevated Temperatures during Heat Treatments of a Pilot Flour Mill: Influence of Sanitation, Temperatures Attained Among Mills Floors, and Costs. Journal of Economic Entomology 2: 709-717.

Brijwani M., Subramanyam B., Flinn P.W., Langemeier M. R. 2010. Structural heat treatments against Tribolium castaneum (Herbst) (Coleoptera:Tenebrionidae): effect of flour depth, life stage and floor. Julius-Kühn-Archiv. 425:625-30.

Dean G. A. 1911. Heat for mill insects. Journal of Economic Entomology 4:142-58.
Dean G. A. 1913. Further data heat as a means of controlling mill insect. Journal of Economic Entomology 6:40-53.

Dosland 0. 1996. Flour mills heating for insect control. Tecnica Molitoria 9: 867-75.

Dowdy A. K., Field P. G. 2002. Heat combined with diatomaceous earth to control the confused flour beetle (Coleoptera: Tenebrionidae) in a flour mill. Journal of Stored Products Research 38:11-22.

Dowdy A. K. 1999. Mortality of red flour beetle, Tribolium castaneum (Coleoptera: Tenebrionidae) exposed to high temperature and diatomaceous earth combinations. Journal of Stored Products Research. 35:175-82.

Failla A., Strano L., Tomaselli G.. 2006. Innovative Building Design Criteria for the Confectionary Industry. CIGR Ejournal 12, Vol. VIII.

Field P., Dowdy A., Marcotte M. 1997. Structural pest control: the use of an enahanced diatomaceus Earth product combined with heat treatment for the control of insect pests in food processing facilities. Agricolture and Agri-Food Canada and the United State Department of Agricolture: Environmental Bureau. Avaiable from: http/home.cc. umanitoba.ca/fieldspg/field/sheatde.htm. Accessed: May 2013.

Guerra P. 2009. Uso delle temperature elevate per il controllo degli insetti nei molini. Esperienze tecniche ed efficacia del metodo. Tecnica Molitoria 2:113-5.

Guerra P., Minetti S., De Cristofano J., Priolo F. 2012. High temperature treatment for pest control in pasta industries. Tecnica Molitoria 11:1110-21.

Mahroof R., Subramanyamb B., Eustace D. 2003. Temperature and relative humidity profiles during heat treatment of mills and its efficacy against Tribolium castaneum (Herbst) life stages. Journal of Stored Products Research 39:555-69.

Massara P. 2007. Disinfestare con aria calda. pp 34-40 in Proc. Conf. L'eliminazione del bromuro di metile per la disinfestazione di industrie alimentari e strutture. Risultati di due anni di esperienze pratiche, 15 February, Bologna, Italy. 
Strano L., Russo P., Lanteri P., Tomaselli G. 2012. Defining the environmental and functional characteristics of the buildings used to produce prickly pear dried puree in terms of food hygiene and safety. Food Control 27:170-177.

Süss L. 2007. Quali possibilità per sostituire il bromuro di metile? pp 11-4 in Proc. Conf. L'eliminazione del bromuro di metile per la disinfestazione di industrie alimentari e strutture. Risultati di due anni di esperienze pratiche, 15 February, Bologna, Italy.

Süss L. 2008. L'impiego del calore nella disinfestazione di industrie alimentari. Igiene Alimenti - disinfestazione \& igiene ambientale $3: 27-8$.
Hulasare R., Subramanyam B., Fields P. G., Abdelghany A.Y. 2010. Heat treatment: A viable methyl bromide alternative for managing stored-product insects in food-processing facilities. Julius-KühnArchiv. 425:664-70.

UNI EN, 1998. Processo edilizio - Classificazione e definizione delle fasi processuali degli interventi edilizi di nuova costruzione. Norma 10723:1998. Ente Nazionale Italiano Di Unificazione.

UNI EN, 1999. Terminologia riferita all'utenza, alle prestazioni, al processo edilizio e alla qualità edilizia. Norma 10838:1999. Ente Nazionale Italiano Di Unificazione. 